\title{
Molecular characterization of crude oil degrading bacterial isolates from polluted soils and cow dung
}

\author{
Felix Adeleke Ikuesan ${ }^{1, *}$, Oluwatoyin Folake Olukunle ${ }^{2}$, Olufemi O \\ Oyelakin $^{3}$ and, Bolatito Esther Boboye ${ }^{2}$
}

\author{
${ }^{1}$ Department of Biological Sciences, Olusegun Agagu University of Science and Technology, Okitipupa, Nigeria \\ ${ }^{2}$ Department of Biotechnology, Federal University of Technology, P. M. B. 704, Akure, Nigeria. \\ ${ }^{3}$ Biotechnology Centre, Federal University of Agriculture, Abeokuta, Nigeria. \\ *Corresponding author
}

\begin{abstract}
Crude oil contamination of agricultural soil is frequent in the Niger-Delta Region of Nigeria and can devastate the soil thereby, negatively affecting the socio-economic lives of the people. This study aimed to characterize twelve bacterial isolates with potential for crude oil degradation using conventional and molecular tools. Isolates with potential for crude oil degradation were selected from among the crude oil degrading bacteria obtained from petroleum contaminated agricultural soils and Cow dung all in Ondo State, Nigeria. The identities of the isolates were confirmed via morphological and biochemical characterization and thereafter the CTAB method was used to prepare the DNA. PCR amplification of I6S rRNA gene of isolates was carried out using universal primers for bacteria. The PCR products were then purified using ethanol precipitation and thereafter sequenced with automated DNA sequencing machine. The sequence data were compared with gene sequences in GenBank database (NCBI) using a BLAST search to find closely related sequences. Phylogenetic analyses of $16 \mathrm{~S} r R N A$ gene sequences were examined in order to determine the evolutionary relatedness of the isolates. Results revealed eight (8) gram positive bacteria consisting of Staphylococcus hominis, Geobacillus sp., Lactobacillus plantarum and four (4) different species of Bacillus, while the gram negative bacterial isolates were Brevundimonas diminuta, Klebsiella oxytoca, Esherichia coli and Enterobacter tabaci with $83 \%$ to 100\% ribosomal RNA homology. Crude oil degrading bacteria characterized in this study can be developed as inoculums with high survival and activity to bioaugment the degradation of crude oil polluted agricultural soil.
\end{abstract}

Keywords_Bioremediation, Cow dung, Crude oil degrading bacteria, Polluted soils, 16S rRNA gene.

\section{INTRODUCTION}

Pollution of the environment due to discharge of petroleum or its derivatives into the environment is a concern to all and sundry including government, environmental researchers and residents of oil producing areas, particularly, the Niger Delta region of Nigeria. Crude oil spill, no matter its source, quantity and size (minor, medium, major or disaster) is potentially harmful to the environment and all forms of biomass (including indigenous micro flora and micro fauna [1, 2]. Among remediation techniques, bioremediation which relies on the use of microorganisms with desired metabolic capabilities to detoxify many hydrocarbon pollutants is most preferred. This method of biological mineralization of petroleum hydrocarbon involving primarily bacteria, yeast and mold is applicable over large area [3], ecosystem friendly, cost effective and non- invasive relative to the physical and chemical methods [4]. Microbial degradation of hydrocarbons by natural population of microorganisms is the major and ultimate natural mechanism by which petroleum hydrocarbon pollutants can be cleaned up from the environment [5]. These microorganisms use petroleum hydrocarbon as carbon and energy source for cellular activities. Microbial remediation of a hydrocarboncontaminated site is accomplished with the activities of diverse group of microorganisms, particularly the indigenous bacteria present in the soil [6]. Hydrocarbon degrading bacteria and fungi are widely distributed in 
marine, freshwater and soil environments. Typical bacteria groups already known for their potentials to degrade hydrocarbons are Pseudomonas sp., Marinobacter sp., Micrococcus sp., Acinetobacter sp., Alcaligenes sp., Bacillus sp., Enterobacter sp. [6,7]. Molds belonging to the genera Aspergillus sp., Penicillium sp., Fusarium sp., Amorphoteca sp., Paecilomyces sp., Talaromyces sp. and the yeasts Candida sp., Yarowia sp., and Pichia sp. have been implicated in hydrocarbon degradation [8]. The process of hydrocarbon biodegradation in soil is however limited by microorganism type and population among other factors [2, 9]. The removal of contaminant by natural attenuation is slow because degrading microbes in soil is only about $10 \%$ of the total heterotrophic population [9]. Many different microorganisms such as Pseudomonas species and the white rot fungus, Phanerochaete chrysosporum are being marketed for use in bioremediation [2]. Klebsiella pneumoniae, Pseudomonas aeruginosa, Escherichia coli, Proteus mirabilis, Alcaligenes faecalis, Bacillus species, Brevundimonas diminuta, Pseudomonas pseudomallei, Staphylococcus hominis, Enterobacter sp, Aspergillus sp. Scopulariopsis brevicaulis, Gliocladium sp, Trichoderma sp, Paecilomyces variotii, Trichophyton menragrophytes, Candida parapsilosis, Kodamaea ohmeri were crude oil degrading bacteria and fungi associated with cow dung and some crude oil contaminated and uncontaminated soils [10]. The studies however do not focus on the molecular identification and genetic relationship among these isolates. Therefore, as a step towards developing inoculum with high survival and activity to bioaugment crude oil biodegradation, it is important to identify the organisms to reasonable level of precision using molecular tools. In this study, bacterial isolates from crude oil polluted soil and Cow dung with potential for crude oil degradation were identified using conventional and molecular tools.

\section{MATERIALS AND METHODS}

\section{1 Sample collection}

Twelve (12) crude oil degrading bacteria previously with potential for crude oil degradation were selected from among the crude oil degrading bacteria obtained from petroleum contaminated agricultural soils of Awoye, Orioke-Iwamimo, Igodan-Lisa, Oba-Ile and Ido-Ani and Cow dung from Shasha, all in Ondo State, Nigeria. These environmental sources had varying amount of total petroleum hydrocarbon (TPH) as evidence of hydrocarbon pollution [10] and their crude oil biodegradation potentials were also reported [11].

2. 2 Sterilization of materials
All media, distilled water and diluents were sterilized by autoclaving at $121^{\circ} \mathrm{C}$ at 15 psi for 15 minutes. Glass wares were sterilized in a hot air-oven at $160^{\circ} \mathrm{C}$ for 2 hours.

2. 3 Purification and Characterization of the crude oil degrading bacterial isolates from soil and cow dung

The isolates were purified by repeated streaking on nutrient agar (NA) and Bushnell- Hass (MSM) incorporated with $1.5 \%$ agar and sterile crude oil $(2 \%)$ and incubated at $28 \pm$ $2^{\circ} \mathrm{C}$ for 48 hours and 14 days (for growth in oil) respectively. Pure and distinct colonies were then inoculated into their respective nutrient agar slant, labeled and incubated at $28 \pm 2^{\circ} \mathrm{C}$ for 48 hours after which they were maintained on nutrient agar (NA) at $4^{\circ} \mathrm{C}$ for further use. The cultural, morphological and biochemical characteristics were also confirmed. These biochemical tests include gram staining, catalase, oxidase, nitrate reduction, citrate utilization, sugar (glucose, maltose, mannitol, sucrose and lactose) fermentation using [12, 13] as standard references.

\section{4 Molecular characterization}

2. 4. 1 DNA extraction of bacterial isolates using CTAB method

DNA isolation is a routine procedure to collect DNA for subsequent molecular or forensic analysis. In this research, Cetyl Trimetyl Ammonium Bromide (CTAB) method of DNA extraction from microbes was used. Twelve bacterial isolates with potential for crude oil degradation were selected from among previously screened isolates from agricultural soils and Cow dung. Overnight grown broth cultures of isolates were respectively transferred to eppendorf tubes and spun down for 2 minutes at 14,000 rpm. The supernatant was discarded and the DNA was extracted using the Cetyl Trimetyl Ammonium Bromide (CTAB) method [14]. The DNA pellets were re-suspended in $100 \mu \mathrm{l}$ of sterile distilled water. DNA concentration of samples were measured on spectrophotometer at $260 \mathrm{~nm}$ and $280 \mathrm{~nm}$ and the genomic purity were determined. Agarose gel electrophoresis was used to determine the quality and integrity of the DNA by size fractionation on $1.0 \%$ agarose gel and visualized on UV light source.

\section{4. 2 Polymerase Chain Reaction (PCR) analysis}

Polymerase chain reaction (PCR) analysis was performed with MJ Research Thermal Cycler (PTC-200 model) using $16 \mathrm{~S}$ (forward and reverse) universal primer for bacteria. The sequence for the $27 \mathrm{~F}$ (5'AGAGTTTGATCATGGCTCAG-3') and 1492R (5'CGGTTACCTTGTTACGACTT-3') [15]. The PCR mix comprises of $1 \mu \mathrm{l}$ of $10 \mathrm{X}$ buffer, $0.4 \mu \mathrm{l}$ of $50 \mathrm{mM} \mathrm{MgCl}$, $0.5 \mu \mathrm{l}$ of $2.5 \mathrm{mM}$ dNTPs, $0.5 \mu \mathrm{l} 5 \mathrm{mM}$ forward primer, $0.5 \mu \mathrm{l}$ 
of $5 \mathrm{mM}$ reverse primer, $0.05 \mu \mathrm{l}$ of 5 units/ $\mu$ lTaq with $2 \mu 1$ of template DNA and 5.05 $\mu$ l of distilled water to make-up $10 \mu 1$ reaction mix. The $\mathrm{PCR}$ profile used was initial denaturation temperature of $94^{\circ} \mathrm{C}$ for 3 minutes, followed by 30 cycles of $94^{\circ} \mathrm{C}$ for 60 seconds, $56^{\circ} \mathrm{C}$ for 60 seconds, $72^{\circ} \mathrm{C}$ for 120 seconds and the final extension temperature of $72^{\circ} \mathrm{C}$ for 5 minutes and the $10^{\circ} \mathrm{C}$ hold.

\section{2. $4.3 \mathrm{Gel}$ Electrophoresis of $16 \mathrm{~S}$ rDNA products}

The PCR products were analyzed on a $1 \%$ TAE agarose gel and stained with ethidium bromide at $80 \mathrm{~V}$ for 45-60 min. The bands were thereafter, visualized using ultraviolet (UV) light trans - illumination and photographed with a digital imaging system (Kodak UV illumination System).

\section{4. 4 Purification of PCR products}

The amplicon was further purified before the sequencing using $2 \mathrm{M}$ sodium acetate washing techniques. To about 10 $\mu 1$ of the PCR product was added $1 \mu 12 \mathrm{M}$ sodium acetate $\mathrm{pH} 5.2$, followed by $20 \mu \mathrm{l}$ absolute ethanol. This was kept at $-20^{\circ} \mathrm{C}$ for 1 hour, spun at 10,000 rpm for 10 minutes, and thereafter washed with $70 \%$ ethanol and air- dried. This was then re-suspended in $5 \mu \mathrm{l}$ sterile distilled water and kept at $4^{\circ} \mathrm{C}$ for sequencing.

\section{4. 5 DNA Sequencing analysis}

The 16S rRNA gene products (forward and reverse primers) of isolates were sequenced. The clean PCR products were subjected to cycle sequencing in both direction using universal primers. The PCR mix used for the sequencing include $0.5 \mu 1$ of BigDye Terminator Mix, $1 \mu 1$ of $5 \mathrm{X}$ sequencing buffer, $1 \mu 1$ of $16 \mathrm{~S}$ forward primer with $6.5 \mu \mathrm{l}$ distilled water and $1 \mu \mathrm{l}$ of the PCR product making a total of $10 \mu 1$. The PCR profile for sequencing is a rapid profile. The initial rapid thermal ramp to $96^{\circ} \mathrm{C}$ for 1 minute followed by 25 cycles of rapid thermal ramp to $96^{\circ} \mathrm{C}$ for 10 seconds, Rapid thermal ramp to $50^{\circ} \mathrm{C}$ for 5 seconds and Rapid thermal ramp to $60^{\circ} \mathrm{C}$ for 4 minutes, then followed by Rapid thermal ramp to $4^{\circ} \mathrm{C}$ and hold forever. This was then re-suspended in $5 \mu 1$ sterile distilled water and kept at $4^{\circ} \mathrm{C}$ for sequencing running. The cocktail mix is a combination of $9 \mu \mathrm{l}$ of Hi Di Formamide with $1 \mu \mathrm{l}$ of purified sequence making a total of $10 \mu \mathrm{l}$. The samples were loaded on the machine (ABI 3100) and the data in form $\mathrm{A}, \mathrm{C}, \mathrm{T}$, and $\mathrm{G}$ was released.

2. 4. 6 Construction of Phylogenetic Tree
The nucleotides sequences obtained were compared with other nucleotides sequences using BLASTn tools of the National Centre for Biotechnology Information (NCBI). The UPGMA method was used to infer the evolutionary history [16]. The software, MEGA7 was used to align all the sequences obtained in this study while all positions containing gaps and missing data were eliminated. The Maximum Composite Likelihood method was used to compute the evolutionary distances [17]. Thereafter, the evolutionary analyses were conducted in MEGA7 [18].

\section{RESULTS AND DISCUSSION}

3. 1 Characterization of crude oil degrading bacterial isolates from soils and cow dung

In the quest to proffer solution to cleaning up the environment polluted with crude oil using microorganisms, twelve potential crude oil degrading bacteria that could be employed in bioremediation techniques were selected from soils and cow dung sources for characterization. Tables 1 and 2 show the detailed morphological and biochemical characteristics of the twelve crude oil degrading bacteria from polluted soils and cow dung. Results indicated that the isolates showed different morphology and responses to gram stain, catalase, oxidase, spore stain, citrate reaction, MP-VP, nitrate reaction and sugar fermentation tests. On the basis of these different features and responses to biochemical tests isolates SS1A, SS1B, SS2A, SS2E, SS3C, SS4A, SS5A and SS5C were tentatively identified as Brevundimonas diminuta, Lactobacillus plantarum, Klebsiella sp, Bacillus megaterium, Bacillus subtilis, Bacillus sp, Bacillus sp. and Geobaccillus sp respectively for the soil samples (Table 1). Cow dung bacterial isolates (Table 2) CD6A, CD6E, CD6J, and CD6K were similarly identified as Escherichia coli, Enterobacter tabaci, Staphylococcus hominis and Geobacillus sp. Interestingly, only Staphylococcus hominis obtained from cow dung was cocci shaped. Thus, the conventional techniques of identification of bacteria revealed four Bacillus species, Brevundimonas sp. and Lactobacillus sp. Klebsiella sp. and Geobacillus sp from polluted soils (table 1) and Escherichia coli, Enterobacter sp., Staphylococcus sp. and Geobacillus sp from cow dung samples (Tables 2). The results obtained agree with the characterization pattern of $[12,13]$. 
Table 1: Characteristics of crude oil degrading bacteria isolated from soil samples

Characteristics Soil isolates

\begin{tabular}{|c|c|c|c|c|c|c|c|c|}
\hline & SS1A & SS1B & SS2B & SS2E & SS3C & SS4A & SS5A & SS5C \\
\hline \multicolumn{9}{|l|}{ Morphological } \\
\hline Colony & Circular & Spherical & Spherical & Cylinder & Elliptical & Undulated & Cylinderical & Elliptical \\
\hline Colour & None & Whitish & None & Yellow & None & None & Brown & None \\
\hline Edge & Entire & Lobate & Regular & Entire & Lobate & Entire & Entire & Entire \\
\hline Surface & Smooth & Rough & Smooth & Smooth & Smooth & Smooth & Smooth & Smooth \\
\hline Cell shape & Rod & Rod & Rod & Rod & Rod & Rod & Rod & Rod \\
\hline Gram stain & - & + & - & + & + & + & + & + \\
\hline Motility & + & - & - & + & + & + & + & + \\
\hline \multicolumn{9}{|l|}{ Biochemical } \\
\hline Catalase & + & - & + & + & - & + & + & + \\
\hline Oxidase & + & - & - & - & - & + & - & - \\
\hline Spore staining & - & - & - & + & + & + & + & + \\
\hline Citrate reaction & - & + & + & + & - & - & + & + \\
\hline MR & + & - & - & + & - & - & + & + \\
\hline VP & - & - & + & - & + & + & - & - \\
\hline $\begin{array}{l}\text { Nitrate } \\
\text { reduction }\end{array}$ & - & - & + & + & + & + & + & + \\
\hline \multicolumn{9}{|l|}{ Fermentation } \\
\hline Glucose & $\mathrm{NC}$ & A & $\mathrm{AG}$ & A & $\mathrm{A}$ & A & A & $\mathrm{A}$ \\
\hline Maltose & $\mathrm{NC}$ & A & $\mathrm{AG}$ & A & A & $\mathrm{NC}$ & A & $\mathrm{NC}$ \\
\hline Mannitol & $\mathrm{NC}$ & A & $\mathrm{AG}$ & A & A & A & A & $\mathrm{A}$ \\
\hline Sucrose & $\mathrm{NC}$ & A & $\mathrm{AG}$ & A & A & $\mathrm{NC}$ & $\mathrm{NC}$ & $\mathrm{NC}$ \\
\hline Lactose & $\mathrm{NC}$ & A & $\mathrm{NC}$ & A & $\mathrm{G}$ & $\mathrm{NC}$ & A & $\mathrm{NC}$ \\
\hline $\begin{array}{l}\text { Possible } \\
\text { Organism }\end{array}$ & $\begin{array}{l}\text { Brev. } \\
\text { diminuta }\end{array}$ & $\begin{array}{l}\text { Lactobacillus } \\
\text { plantarum }\end{array}$ & $\begin{array}{l}\text { Klebsiella } \\
\text { oxytoca. }\end{array}$ & $\begin{array}{l}\text { Bacillusm } \\
\text { egaterium }\end{array}$ & $\begin{array}{l}\text { Bacillus } \\
\text { subtilis }\end{array}$ & $\begin{array}{l}\text { Bacillus } \\
\text { aryabhattai }\end{array}$ & Bacillus sp. & $\begin{array}{l}\text { Geobacillu } \\
\text { s sp. }\end{array}$ \\
\hline
\end{tabular}

Legend: $\mathrm{A}=$ Acid production only, $\mathrm{AG}=$ Acid \& Gas production, $\mathrm{G}=\mathrm{Gas}$ production, $\mathrm{NC}=$ No change, $+=$ positive, $-=$ negative,SS1A and SS1B are isolates from Awoye soil sample, SS2B and SS2E are isolates from Orioke- Iwamimo soil, SS3C is isolate from Igodan- Lisa soil, SS4A is isolate from Oba- Ile soil, SS5A and SS5C are isolates from Ido- Ani soil

The bacterial isolates in this work belong to both the gram positive and gram negative groups. These findings corroborate the report that both gram negative and positive bacteria have been implicated in the mineralization of hydrocarbon pollutants [19]. This study also revealed that gram positive crude oil degrading bacteria are ubiquitously distributed, diverse and dominant in all the soils samples and cow dung. This finding deviates from the reports that gram positive bacteria if detected in bioremediation are never diverse and dominant [20]. Also, the ability to isolate high number of certain crude oil degrading microorganisms from these environments is commonly taken as evidence that those microorganisms are the most active degraders in that environment and can be used in the bioremediation of petroleum oil contaminated sites [21, 22]. This probably suggests that these organisms are able to adapt to different hydrocarbons and varying environmental parameters since samples were collected from different locations. $B$. 
diminuta belongs to the phylum Proteobacteria, class Alphaproteobacteria and order Caulobacter. B. diminuta has been reported to have considerable ability for bioremediation following a bioremediation study of sea water contaminated with diesel in China [23]. Staphylococcus hominis, a gram negative and coagulase negative bacterium, was also isolated from oil contaminated soil [24]. It was observed from this work that the dominant bacterial species were Bacillus, belonging to the phylum Firmicutes. The abundance of Bacillus sp. in the crude oil polluted soils shows that they are indigenous to the soil. The presence of Bacillus species have been reported by different researchers in crude oil contaminated soils with the ability to degrade oil [25], thereby, using crude oil as sole source of carbon and energy $[22,25]$

Table 2: Characteristics of crude oil degrading bacteria isolated from cow dung

\begin{tabular}{|c|c|c|c|c|}
\hline \multirow[t]{2}{*}{ Characteristics } & \multicolumn{4}{|c|}{ Cow dung isolates } \\
\hline & CD6A & CD6E & CD6J & CD6K \\
\hline \multicolumn{5}{|l|}{ Morphological } \\
\hline Colony & Circular & Circular & Circular & Elliptical \\
\hline Colour & Greyish & Creamy & Creamy & None \\
\hline Edge & Entire & Lobate & Entire & Entire \\
\hline Surface & Smooth & Dull & Smooth & Smooth \\
\hline Cell shape & Rod & Rod & Cocci & Rod \\
\hline Gram stain & - & - & + & + \\
\hline Motility & + & + & - & + \\
\hline \multicolumn{5}{|l|}{ Biochemical } \\
\hline Catalase & + & + & + & + \\
\hline Oxidase & - & - & - & - \\
\hline Spore staining & - & - & - & + \\
\hline Citrate reaction & - & + & + & + \\
\hline MR & + & - & + & + \\
\hline VP & - & + & + & - \\
\hline Nitrate reduction & + & + & + & + \\
\hline \multicolumn{5}{|l|}{ Sugar Fermentation } \\
\hline Glucose & $\mathrm{AG}$ & AG & AG & AG \\
\hline Maltose & $\mathrm{AG}$ & A & A & $\mathrm{NC}$ \\
\hline Mannitol & $\mathrm{AG}$ & A & A & A \\
\hline Sucrose & $\mathrm{NC}$ & A & A & $\mathrm{NC}$ \\
\hline Lactose & $\mathrm{AG}$ & A & A & $\mathrm{NC}$ \\
\hline Possible Organism & Escherichia coli & Enterobactersp & Staph.hominis & Geobacillussp \\
\hline
\end{tabular}

LEGEND: $\mathrm{A}=$ Acid Production only, $\mathrm{AG}=$ Acid \& Gas Production, $\mathrm{G}=$ Gas Production, NC = No Change, $+=$ Positive, $-=$ Negative , CD6A, CD6E, CD6J and CD6K are isolates from cow dun 


\section{2 Molecular identity of the bacterial isolates}

Plate 1 shows the agarose gel electrophoresis of twelve bacterial isolates subjected to molecular identification using $16 \mathrm{~S}$ universal primer. Fig. 1 shows the phylogenetic tree of the bacterial isolates while table 3 shows the nearest relative, accession numbers and the percentage homology of the isolates. The blasting of the sequence also revealed that there are eight types of bacteria genera present in the samples. These include four Bacillus species, Brevundimonas diminuta, Esherichia coli, Enterobacter sp. Geobacillus, Stahylococcus hominis, Lactobacillus plantarum and Klebsiella oxytoca. All the bacteria obtained in this work had between $83 \%$ and $100 \%$ homology with the bacterial isolates deposited in the NCBI data.

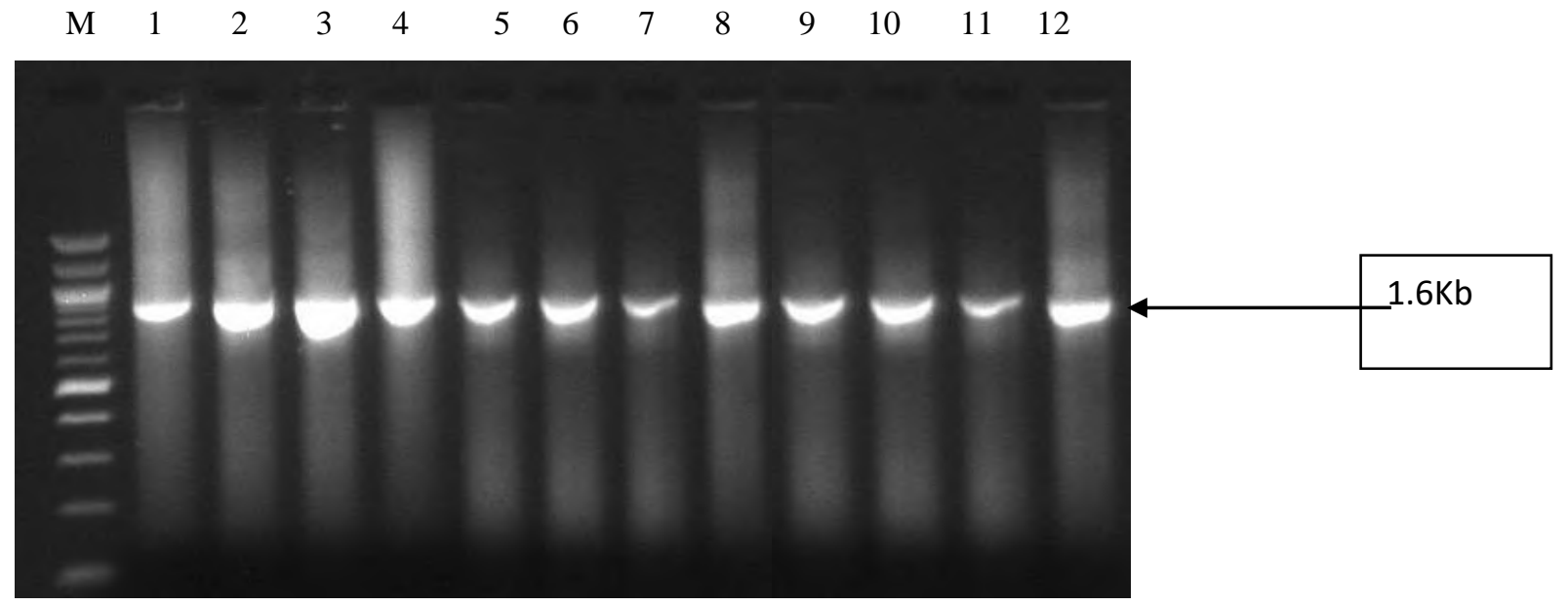

Plate 1: Agarose gel electrophoresis of DNA of the bacterial isolates using 16S universal primer

(100 basepair ladder)

Legend: $\mathrm{M}=$ Molecular Weight Marker/Ladder $(1 \mathrm{~kb})$

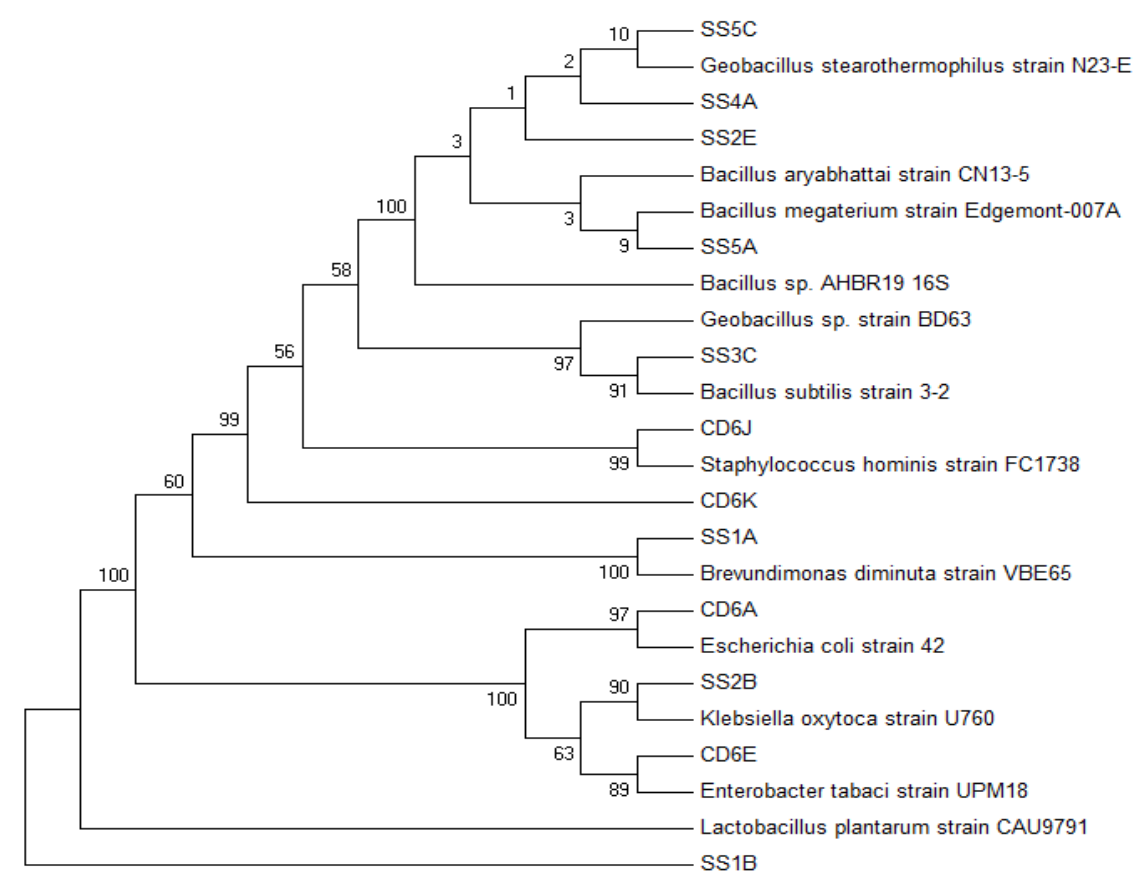

Fig.1: Phylogenetic tree based on partial 16S rRNA gene sequences analysis indicating the relationships between crude oildegrading bacteria from polluted soils and cow dung and the related strains from the Gene Bank. 
International Journal of Environment, Agriculture and Biotechnology, 5(3)

May-Jun, 2020 / Available: https://ijeab.com/

Table 3: Complete nucleotides blast of 16S rRNA genes from crude oil degrading bacteria

\begin{tabular}{|c|c|c|c|c|}
\hline $\begin{array}{l}\text { Isolate } \\
\text { Code }\end{array}$ & Source & Organisms & $\begin{array}{l}\text { Accession } \\
\text { Number }\end{array}$ & (\%)Identity \\
\hline SS1A & Soil & $\begin{array}{l}\text { Brevundimonas diminuta strain } \\
\text { VBE65 }\end{array}$ & MG027643.1 & 100 \\
\hline SS1B & Soil & $\begin{array}{l}\text { Lactobacillus plantarum strain } \\
\text { CAU9791 }\end{array}$ & MF425505.1 & 83 \\
\hline SS2B & Soil & Klebsiella oxytoca strain U760 & K4572971.1 & 99 \\
\hline SS2E & Soil & $\begin{array}{l}\text { Bacillus megaterium strain } \\
\text { Edgemont-007A }\end{array}$ & MF965192.1 & 99 \\
\hline SS3C & Soil & Bacillus subtilis strain 3-2 & JX051359.1 & 99 \\
\hline SS4A & Soil & Bacillus aryabhattai strain CN13-5 & MH762878.1 & 100 \\
\hline SS5A & Soil & Bacillus sp. strain AHBR19 & KF241532.1 & 100 \\
\hline SS5C & Soil & $\begin{array}{l}\text { Geobacillus stearothermophilus } \\
\text { strain N23-E }\end{array}$ & KF768847.1 & 100 \\
\hline CD6A & Cow dung & Escherichia coli strain 42 & MH671423.1 & 100 \\
\hline CD6E & Cow dung & Enterobacter tabaci UPM18 & MH794127.1 & 99 \\
\hline CD6J & Cow dung & $\begin{array}{l}\text { Staphylococcus hominis } \\
\text { strain FC1738 }\end{array}$ & MH665980.1 & 100 \\
\hline CD6K & Cow dung & Geobacillus sp. strain BD63 & MF767892.1 & 94 \\
\hline
\end{tabular}

Legend: SS1A and SS1B are isolates from Awoye soil sample, SS2B and SS2E are isolates from Orioke- Iwamimo soil, SS3C is isolate from Igodan- Lisa soil, SS4A is isolate from Oba- Ile soil, SS5A SS5C are isolates from Ido- Ani soil, CD6A, CD6E, CD6J and CD6K

The molecular techniques used in this study to identify bacteria were based on the conserved sequence of the $16 \mathrm{~S}$ rRNA genes that were amplified by PCR [26]. The molecular weights of the PCR amplification fragments obtained were about 1.6kb each (Plate 1). The results from the conserved sequence of the 16S rRNA coupled with the nucleotide sequences revealed that the twelve bacteria isolates were closely related to Brevundimonas diminuta strainVBE65, Lactobacillus plantarum strain CAU979, Klebsiella oxytoca strain U760, Bacillus megaterium strain Edgemout-007A,
Bacillus subtilis strain 3-2, Bacillus aryabhattai strain CN135, Bacillus sp. strainAHBR19,Geobacillus stearothermophilus strain N23-E, Escherichia coli strain 42, Enterobacter tabaci UPM18, Staphylococcus hominis strain FC1738 and Geobacillus sp. strain BD63. The high percentage $(99-100 \%)$ similarities observed between the 16S rRNA gene, partial sequences of ten of the bacterial isolates and previously identified bacteria in the GeneBank, indicates that they are homologous to each other (Table 3).The Phylogenetic tree, based on partial bacterial $16 \mathrm{~S}$ 
rRNA gene sequence analysis, indicates the relationships between the isolated microbes and the related genera of the phylum Proteobacteria and Firmicutes. The evolutionary history was inferred by using the statistical method of UPGMA. The percentage of replicate trees in which the associated taxa clustered together in the bootstrap test $(1000$ replicates) is shown next to the branches. The higher the bootstrap value, the more reliable the phylogenetic analysis. The code indicates the microorganisms used in this study. The strains of reference species are indicated (Fig. 2).

\section{CONCLUSION}

This study has been able to characterize crude oil degrading bacteria from environmental sources (soil and cow dung) using both conventional and molecular techniques. The study revealed the molecular identity of crude oil degrading bacteria from environmental sources that can be harvested as biomass and marketed for use as inoculums to enhance bioremediation of polluted sites in the future.

\section{ACKNOWLEDGEMENT}

The authors are grateful to the Department of Microbiology, The Federal University of Technology, Akure, Nigeria for providing conducive environment and materials for this study.

\section{REFERENCES}

[1] Shukry W. M., Al-Hawas G. H. S., Al-Moaikal R. M. S. and El-Bendary M. A., (2013). Effect of petroleum crude oil on mineral nutrient elements, soil properties and bacterial biomass of the Rhizosphere of Jojoba. British J. Environ. and Climate Change., 3(1), 103-118

[2] Odeyemi O., Two Centuries of Oil and Gas (1860 - 2060) (2014) www.universalacacdemicservices.org.

[3] Bento F. M., Camarago F. A. O., Okeke B. C. and Frankenberger W. T. (2005). Comparative bioremediation of soil contaminated with diesel oil by natural attenuation, biostimulation and bioaugumentation. Bioresour. Technol. 96, 1049-1055

[4] Farber, R., Rosenberg, A., Rosenfeld, S., Banet, G. and Cahan, R. (2019). Bioremediation of artificial diesel- contaminated soil using bacterial consortium immobilized to plasmapretreated wood waste. Microorganisms; 7:1-17

[5] Farag S. and Soliman N. A., (2011). Biodegradation of crude oil petroleum oil and environmental pollutants by Candida tropicals strain, Braz. Arch Biol. Technol, 54(4), 842 - 830
[6] Jain P. K., Gupta V. K., Gaur R. K., Lowry M., Jaroli D. P. and Chauhan U. K. (2011) Bioremediation of petroleum oil contaminated soil and Water. Res. J. Environ.Toxicol., 5(1), 126

[7] Bhattacharya D, Sarma P. M., Krishnan S., Mishra S. and Lal B. (2002). Evaluation of genetic diversity among Pseudomonas citronellolis strain isolated from oily sludge contaminated sites. Appl. Environ. Microbiol, 663, 1435-1441

[8] Chaillan F., Le Fleche, A., Bury E., Phantavong Y., Grimont P., Saliot A. and Oudot, J. (2004) Identification and biodegradation potential of tropical aerobic hydrocarbondegrading microorganisms. Res. J. Microbiol.,155, 587 - 595

[9] Dzionek, A., Wojcieszynska, D and Guzik, U. (2016). Natural carriers in bioremediation: A Review. Electronic Journal of Biotechnolgy; 23:28-36

[10] Ikuesan F. A, Boboye B. E and Adetuyi F. C. (2016). The microbiological and physicochemical properties of some crude oil contaminated and uncontaminated agricultural soils in Ondo State, Nigeria. Pyrex J. Microbiol Biotechnol, 2(1), 1-8

[11] Ikuesan, F. A. (2017) Evaluation of crude oil degradation potentials of some indigenous soil microorganisms. $J$. Scientific Res. and Reports. 13(5),1-9

[12] Holt J. G., Krieg N.R., Sneath P. H, Stanley J. J and Williams S. T. (1994) Bergy's manual of determinative bacteriology. Williams and Wilkins Company, Baltimore.

[13] Sneath P. H. A., Mair N. S., Sharpe M. E and Holt J. G. (2009). Bergy's Manual of Systematic Bacteriology, Balimore.: In Kleins and Wilkins

[14] Bin, L., Jin-pin Z., Wei-guo H, Sheng Y. and Donald L. M. (2008). PCR-based sensitive detection of the edible fungus Boletus edulis. Electro. J. Biotechnol. 11(3), 1- 9

[15] Akinyemi, A. A. and Oyelakin O. O. (2014). Molecular characterization of bacteria isolates from farm-raised catfish Clarias gariepinus (Burchell,1822). British Microbiol. Res. J.,4(12), 1345-1352

[16] Sneath, P. H. A. and Sokal, R. R. (1973). Numerical Taxonomy; The principles and practice of numerical classification. San. Francisco, Free, 573 pp

[17] Tamura, K., Nei M. and Kumar S. (2004). Prospect for inferring very large phylogenies by using the neighbor-joining method. Proc Natl Acad Sci USA, 101, 1030-11035

[18] Kumar, S., Stecher G. and Tamura K. (2016). MEGA7: Molecular evolutionary genetic analysis version 7.0 for bigger datasets. Mol. Biol. Evol.,; 33, 1870-1874

[19] Salam, L. B., Obayori O. S., Akashoro O. S. and Okogie G. O. (2011). Biodegradation of Bonny light crude oil by Bacteria isolated from contaminated soil. Inter. J. Agric. Biol., 13, 245250

[20] Kaplan, C. W. and Kitts C. L. (2004). Bacteria succession in a petroleum land treatment unit. Appl. Environ. Microbiol.,70, $1777-1786$ 
[21] Atlas R. M. and Bartha R. (1998). Fundamentals and applications.(4 ${ }^{\text {th }}$ edition), Benjamin/Cummings Publishing Co. Inc., California, USA., 523-530

[22] Al- Wasify, R. S, Hamed, S. R. (2014). Bacterial Biodegradation of crude oil using isolates. Inter. J. Bacteriol.; $1-8$

[23] Wang, X., Wang, X.., Liu, M., Zhou, L., Gu, Z and Zhao J. (2015). Bioremediation of marine oil pollution by Brevundiminas diminuta effect of salinity and nutrients. Desalination and Water Treatment. DOI: 10.1080/19443994.2015.1106984

[24] Krishnareni, M. (2018). Isolation and characterization of Staphyloccus JX961712 for oil contaminated soil. J. Pharm. Res., 7(3), 252-256

[25] Kumar, V. Makkar, H. P. S and Becker K. (2011). Detoxified Jatropha curcas Kernel Meal as a dietary protein source; Growth performance, nutrient utilization and digestive enzymes in common carp (Cyprinus carpio . L.) Fingerlings. Aquacult. Nutr., 17 (3), 313-326.

[26] Farrelly, V., Rainey F. A. and Stackebrandt E. (1995). Effect of genome size and rrn gene copy number on PCR amplification of $16 \mathrm{~S}$ rRNA genes from a mixture of bacterial species. Appl. Environ. Microbiol., 61, 2798-2801 